\title{
Peningkatan Kemampuan Bahasa Anak Usia 5-6 Tahun Melalui Penggunaan Media Boneka Jari Di Tk Pelangi Genyem Kabupaten Jayapura
}

\author{
Sirjon $^{1 *)}$, Hana Falentina Yaung ${ }^{2}$ \\ ${ }^{1,2}$ Program Studi PG PAUD Universitas Cenderawasih \\ ${ }^{*}$ E-mail: sirjon@fkip.uncen.ac.id
}

\begin{abstract}
Improving Language Skills for Children aged 5-6 Years Through the Use of Finger Puppet Media at Pelangi Genyem Kindergarten, Jayapura Regency. The purpose of this study was to improve skills through the use of finger puppets for children aged 5-6 years at Pelangi Genyem Kindergarten, Jayapura Regency. This research is a classroom action research. The research subjects were 15 children, consisting of 6 boys and 9 girls. This research uses the action model of Kemmis and Mc Taggart. The research was carried out as many as 6 actions divided into 2 cycles. The results showed an increase in children's language skills. This can be seen from the initial condition of children's language skills which only reached $48.33 \%$. In the first cycle of action 1 became 53.88\%, and increased again in the first cycle of action 2 to $60 \%$, and in the first cycle of action 3 increased to $66.67 \%$. Furthermore, in the first cycle of action 1 it became $71.11 \%$, in the first cycle of action 2 the value increased to $76.11 \%$, and in the second cycle of action 3 increased again to $81.66 \%$. Therefore, the key is that the use of finger puppet media can improve language skills in children aged 5-6 years at Pelangi Genyem Kindergarten, Jayapura Regency.
\end{abstract}

Keywords: Child; Language; Finger Puppets; Media.

\begin{abstract}
Abstrak. Peningkatan Kemampuan Bahasa Anak Usia 5-6 Tahun Melalui Penggunaan Media Boneka Jari Di Tk Pelangi Genyem Kabupaten Jayapura. Tujuan penelitian ini adalah untuk meningkatkan kemampuan bahasa melalui penggunaan media boneka jari pada anak usia 5-6 tahun di TK Pelangi Genyem Kabupaten Jayapura. Penelitian ini merupakan penelitian tindakan kelas. Subjek penelitian berjumlah 15 anak, yang terdiri dari 6 laki-laki dan 9 perempuan. Penelitian menggunakan model tindakan dari Kemmis dan Mc Taggart. Penelitian dilakukan sebanyak 6 tindakan yang terbagi dalam 2 siklus. Hasil penelitian menunjukkan adanya peningkatan kemampuan berbahasa anak. Hal itu dapat dilihat dari kondisi awal kemampuan berbahasa anak yang hanya mencapai 48,33\%. Pada siklus 1 tindakan 1 menjadi 53,88\%, dan meningkat lagi pada siklus 1 tindakan 2 menjadi 60\%, dan pada siklus 1 tindakan 3 meningkat menjadi 66,67\%. Selanjutnya pada siklus 1 tindakan 1 menjadi 71,11\%, Pada siklus 1I tindakan 2 nilai meningkat menjadi $76,11 \%$, dan pada sikus II tindakan 3 meningkat lagi menjadi $81,66 \%$. Oleh karena itu disimpulkan bahwa penggunaan media boneka jari dapat meningkatkan kemampuan bahasa pada anak usia 5-6 tahun di TK Pelangi Genyem Kabupaten Jayapura.
\end{abstract}

Kata Kunci: Anak; Bahasa; Boneka Jari; Media. 


\section{PENDAHULUAN}

Upaya menciptakan generasi penerus bangsa yang cerdas membutuhkan adanya proses pendidikan (Anjeli \& Latifah, 2021). Proses pendidikan tersebut harus dapat memfasilitasi perkembangan peserta didik agar dapat berkembang dalam berbagai aspek perkembangannya. Dalam upaya memfasilitasi perkembangan berbagai aspek tersebut, pendidik harus mampu merancang pembelajaran yang sejalan dengan usia, kebutuhan serta minat anak. Aspek perkembangan anak adalah keseluruhan potensi yang dimiliki anak atau the whole child (Suyanto, 2005). Aspek perkembangan yang dimaksud adalah fisik motorik, nilai moral dan agama, kognitif, seni, sosial emosional, dan bahasa.

Aspek yang dapat mengembangkan komunikasi anak adalah aspek bahasa. Aspek bahasa sangat penting untuk dikembangkan sebab merupakan media komunikasi (Aprillina et al., 2020). Tanpa bahasa, anak tidak akan dapat berinteraksi dengan kelompok sosialnya. Menurut (Ramadani, 2016), bahasa adalah alat untuk mengungkapkan pikiran serta pengetahuan seseorang kepada orang lain. (Hidayati \& Affrida, 2020) menambahkan bahwa bahasa adalah alat untuk untuk menyampaikan gagasan, pikiran, konsep, serta perasaan ketika seseorang sedang berinteraksi dengan lingkungannya. Selanjutnya (Dewi et al., 2016) mengemukakan bahwa bahasa merupakan alat komunikasi yang dapat menciptakan interaksi sosial yang aktif dan produktif.

Merujuk hasil observasi awal di TK Pelangi Kabupaten Jayapura terkait dengan perkembangan bahasa anak, diperoleh data bahwa dari 15 orang anak, tidak ada yang mampu mencapai kriteria perkembangan BSB, terdapat 1 anak $(6,7 \%)$ pada kriteria BSH, 3 anak (20\%) berada pada kriteria MB, serta terdapat 11 anak $(73,3)$ yang berada pada kriteria BB. Data ini memberikan bukti bahwa kemampuan bahasa anak masih rendah. Mayoritas anak masih sulit dalam mengenal abjad, mengucapkan suku kata awal, menyebutkan kembali 2-3 kalimat sederhana, menghubungkan tulisan sederhana dengan simbolnya, serta membaca gambar dalam buku cerita. Rendahnya kemampuan bahasa anak tersebut, disebabkan oleh kurangnya perhatian guru terhadap esensi penggunaan media pembelajaran, pembelajaran tidak dikemas dengan menarik, serta kurangnya upaya untuk menstimulus anak agar terlibat aktif dalam pembelajaran.

Permasalahan tersebut di atas, memerlukan adanya perbaikan dalam proses pembelajarannya. Diperlukan adanya penggunaan media pembelajaran yang lebih bervariasi serta memuat esensi bermain. (Elisa et al., 2020) mengatakan bahwa konsep/materi pembelajaran akan lebih mudah dipahami anak jika guru menggunakan media pembelajaran. Media alternatif yang dapat digunakan adalah media boneka jari (Elisa et al., 2020). Menurut (Yosastra et al., 2013), boneka jari adalah boneka yang memiliki karakter tertentu yang dipasangkan pada jari-jari tangan. Sedangkan menurut (Sukerti, 2013), boneka jari adalah media pembelajaran yang dapat digerakkan melalui jari tangan. Bentuknya dapat digambar langsung pada ujung jari tangan atau dibuat dari kain flanel yang dibentuk sesuai dengan karakter yang ingin dimainkan. Selanjutnya, (Triyuwanti \& Widha, 2018) mengemukakan bahwa media boneka jari sangat efektif dalam mengembangkan pembendaharaan kata, kemampuan menyimak, serta kemampuan bercerita. Penggunaan media boneka jari sangat penting, karena media boneka jari dapat mendorong anak untuk menggunakan bahasa (Ayuni et al., 2014). Boneka jari memiliki manfaat untuk meningkatkan daya tarik pembelajaran, meningkatkan minat dan motivasi anak, mengembangkan imajinasi, meningkatkan keaktifan anak, serta dapat menciptakan kenyamanan bermain bagi anak (Sukerti, 2013). 
Penelitian tentang penggunaan boneka jari telah banyak diteliti oleh peneliti sebelumnya, seperti penelitian (Oktiawati et al., 2020), (Yosastra et al., 2013), (Ayuni et al., 2014), (Sukerti, 2013), (Amelia \& Marsella, 2018), serta (Khairunnisa \& Oye, 2020). Dari berbagai penelitian terdahulu di atas, dapat diketahui bahwa belum ada peneliti lain yang melakukan penelitian dalam meningkatkan kemampuan bahasa anak secara utuh melalui penggunaan media boneka jari. Sebagian meneliti penggunaan media boneka jari untuk variabel interpersonal, kecerdasan emosional, operasi pengurangan, serta kemampuan bahasa yang terbatas pada kemampuan berbicara saja Selanjutnya, penelitian terdahulu kebanyakan dilaksanakan di wilayah barat Indonesia seperti di Kalimantan dan Aceh dan sepengetahuan peneliti belum dilaksanakan di wilayah Timur, khususnya di Jayapura. Oleh karenanya, peneliti melakukan penelitian dengan judul "Peningkatan Kemampuan Bahasa Anak Usia 5-6 Tahun Melalui Penggunaan Media Boneka Jari di TK Pelangi Genyem Kabupaten Jayapura".

\section{METODE}

Jenis penelitian ini adalah tindakan kelas. Tindakan menggunakan model dari Kemmis dan Mc Taggart yang dapat dilihat pada gambar 1.

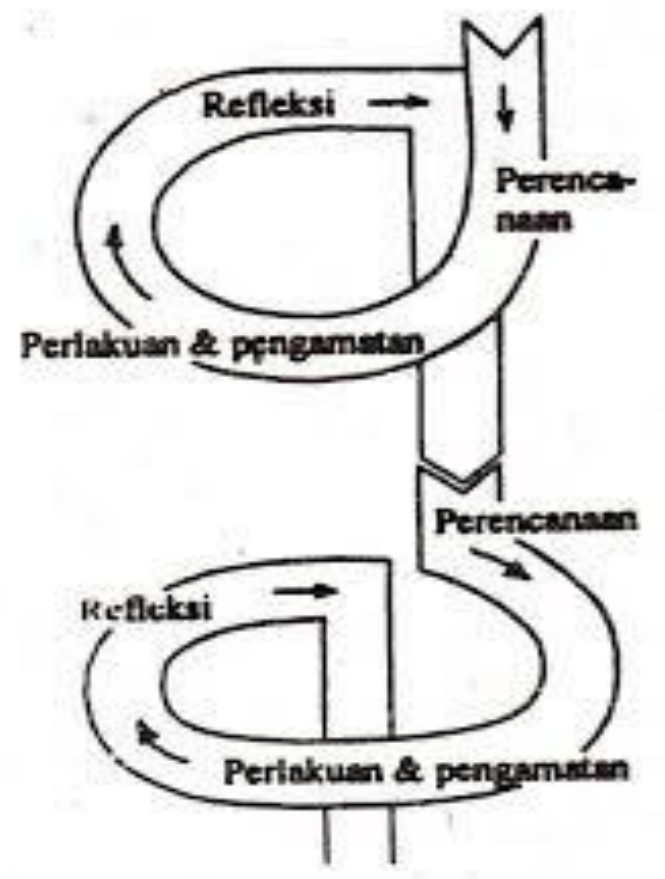

Gambar 1. Alur Model Kemmis dan Mc Taggart

Penelitian dilaksanakan di TK Pelangi Genyem Kota Kabupaten Jayapura dengan subjek penelitian sebanyak 15 orang anak. Tindakan dilakukan pada semester 2 Tahun Ajaran 2020-2021. Metode pengumpulan data menggunakan observasi dan dokumentasi. Data dianalisis secara kuantitatif dan kualitatif. Analisis kuantitatif dilakukan dengan mencari nilai rerata, serta persentase keberhasilan perkembangan bahasa anak. Sedangkan analisis kualitatif dilakukan dengan mendeskripsikan informasi berbentuk kalimat yang memberikan gambaran tentang perkembangan bahasa anak melalui penggunaan media boneka jari. 


\section{HASIL}

\section{Pra Siklus}

Hasil observasi awal di TK Pelangi Genyem Kota Kabupaten Jayapura menunjukkan data berikut:

Tabel 1. Data Awal Perkembangan Bahasa Anak di TK Pelangi Genyem Kota Kabupaten Jayapura

\begin{tabular}{|c|c|c|c|c|c|c|}
\hline \multirow{2}{*}{ No } & \multirow{2}{*}{$\begin{array}{l}\text { Nama } \\
\text { Anak }\end{array}$} & \multicolumn{3}{|c|}{ Aspek-Aspek yang dikembangkan } & \multirow{2}{*}{$\%$} & \multirow{2}{*}{ Ket } \\
\hline & & Menyimak & Berbicara & Menulis & & \\
\hline 1 & An & 站枟 & * & 站枟 & 41,67 & $\mathrm{BB}$ \\
\hline 2 & $\mathrm{Al}$ & $\star \star \star \Delta$ & 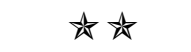 & $\star$ & 41,67 & $\mathrm{BB}$ \\
\hline 3 & $\mathrm{Ag}$ & 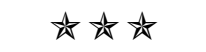 & $\star$ & $\star \star *$ & 50 & $\mathrm{BB}$ \\
\hline 4 & Bs & 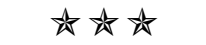 & $\star$ & *t & 50 & BB \\
\hline 5 & $\mathrm{Ca}$ & 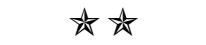 & $\star$ & $\star$ & 33,33 & BB \\
\hline 6 & Ds & 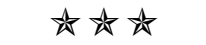 & 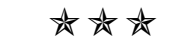 & 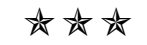 & 75 & $\mathrm{BSH}$ \\
\hline 7 & Ec & 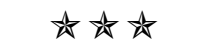 & $\star \star$ & $\star$ & 50 & $\mathrm{BB}$ \\
\hline 8 & Ic & 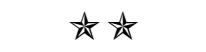 & 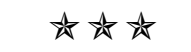 & $\star \star \star 力$ & 58,33 & MB \\
\hline 9 & Jy & $\star \star \star * ⿰ 幺$ & ** & *中心 & 66,67 & $\mathrm{MB}$ \\
\hline 10 & $\mathrm{Kt}$ & $\star \star \star \Delta$ & 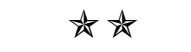 & 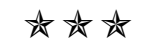 & 58,33 & MB \\
\hline 11 & $\mathrm{Me}$ & 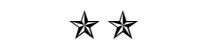 & $\star \star t$ & *t & 50 & $\mathrm{BB}$ \\
\hline 12 & Ma & $\star$ & 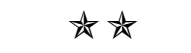 & $\star$ & 33,33 & $\mathrm{BB}$ \\
\hline 13 & Mi & $\star$ & 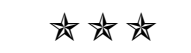 & $\star$ & 41,67 & $\mathrm{BB}$ \\
\hline 14 & $\mathrm{Nv}$ & 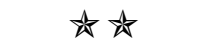 & $\star \star \star \Delta$ & $\star$ & 41,67 & $\mathrm{BB}$ \\
\hline 15 & $\mathrm{Nw}$ & * & t & *t & 33,33 & BB \\
\hline \multicolumn{3}{|c|}{ Jumlah Rata-Rata $=725 / 15$} & & & \multicolumn{2}{|c|}{$48,33 \%$} \\
\hline
\end{tabular}

Keterangan :
a. $* t * t$
$:$ BSB $\geq 80 \%$
b. $* * *$
: BSH $70 \%-79 \%$.
c. $* \star *$
: MB $\quad 56 \%-69 \%$.
d. $\star \star x$
: BB $\quad 0 \%-55 \%$.

Data pada tabel 1 memberikan informasi bahwa dari 15 orang anak, tidak ada yang mampu mencapai kriteria BSB, 1 anak $(6,7 \%)$ berada pada kriteria BSH, 3 anak $(20 \%)$ berada pada kriteria MB, serta terdapat 11 anak $(73,3)$ yang berada pada kriteria BB. Data tersebut menunjukkan rendahnya perkembangan bahasa anak Siklus 1 berikut:

Hasil observasi tindakan pada siklus 1 tindakan 1, menunjukkan data sebagai

Tabel 2. Data Perkembangan Bahasa Anak Pada Siklus 1 Tindakan 1

\begin{tabular}{|c|c|c|c|c|c|c|}
\hline \multirow{2}{*}{ No } & \multirow{2}{*}{$\begin{array}{c}\text { Nama } \\
\text { Anak }\end{array}$} & \multicolumn{3}{|c|}{ Aspek-Aspek yang dikembangkan } & \multirow{2}{*}{$\%$} & \multirow{2}{*}{ Ket } \\
\hline & & Menyimak & Berbicara & Menulis & & \\
\hline 1 & An & 加 & औ & 办办办 & 50 & $\mathrm{BB}$ \\
\hline 2 & $\mathrm{Al}$ & *t & * * & $\star$ & 41,67 & $\mathrm{BB}$ \\
\hline 3 & $\mathrm{Ag}$ & 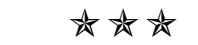 & $\star \star \star$ & * * & 58,33 & MB \\
\hline 4 & Bs & 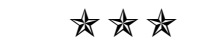 & $\star$ & $\star \star \star \Delta$ & 50 & $\mathrm{BB}$ \\
\hline 5 & $\mathrm{Ca}$ & $\star \star \star \Delta$ & $\star \star \star \Delta$ & 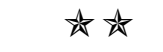 & 50 & BB \\
\hline 6 & Ds & 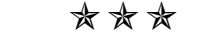 & 炏炏 & 虾办 & 75 & BSH \\
\hline
\end{tabular}




\begin{tabular}{|c|c|c|c|c|c|c|}
\hline \multirow{2}{*}{ No } & \multirow{2}{*}{$\begin{array}{l}\text { Nama } \\
\text { Anak }\end{array}$} & \multicolumn{3}{|c|}{ Aspek-Aspek yang dikembangkan } & \multirow{2}{*}{$\%$} & \multirow{2}{*}{ Ket } \\
\hline & & Menyimak & Berbicara & Menulis & & \\
\hline 7 & Ec & 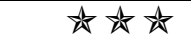 & *t & 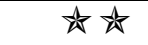 & 58,33 & MB \\
\hline 8 & Ic & $\star \star \star * ⿰ 幺$ & 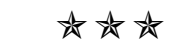 & 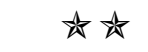 & 66,67 & MB \\
\hline 9 & Jy & 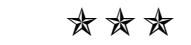 & 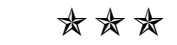 & 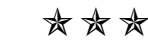 & 75 & $\mathrm{BSH}$ \\
\hline 10 & $\mathrm{Kt}$ & $\star \star \star t$ & $\star \star \star t$ & 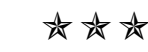 & 58,33 & MB \\
\hline 11 & $\mathrm{Me}$ & 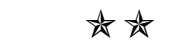 & 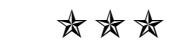 & $\star \star \star \Delta$ & 58,33 & MB \\
\hline 12 & $\mathrm{Ma}$ & 出出 & $\star \star * t$ & $\star$ & 41,67 & $\mathrm{BB}$ \\
\hline 13 & Mi & $\star$ & 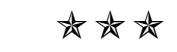 & 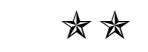 & 50 & $\mathrm{BB}$ \\
\hline 14 & $\mathrm{Nv}$ & * * & $\star \star \star$ & $\star$ & 41,67 & BB \\
\hline 15 & $\mathrm{Nw}$ & * & $\star \star \star t$ & 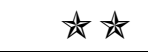 & 41,67 & $\mathrm{BB}$ \\
\hline
\end{tabular}

Keterangan :

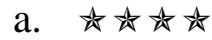
: BSB $\geq 80 \%$
b. $\star \star \star \star * t$
: BSH $70 \%-79 \%$.
c. $\star \star \star x$
: MB $56 \%-69 \%$.
d. $\star x$
: BB $\quad 0 \%-55 \%$.

Data pada tabel 2 menunjukkan bahwa belum ada anak yang berada pada kriteria penilaian BSB, 2 anak $(13,33 \%)$ berada pada kriteria BSH, 5 anak $(33,33 \%)$ berada pada kriteria MB, serta masih terdapat 8 anak $(33,33 \%)$ yang berada pada kriteria BB. Data tersebut menunjukkan bahwa perkembangan bahasa anak belum berkembang dengan baik, sehingga perlu dilanjutkan pada tindakan 2 .

Setelah melakukan tindakan 2, maka diperoleh data sebagai berikut:

Tabel 3. Data Perkembangan Bahasa Anak Pada Siklus 1 Tindakan 2

\begin{tabular}{|c|c|c|c|c|c|c|}
\hline \multirow{2}{*}{ No } & \multirow{2}{*}{$\begin{array}{l}\text { Nama } \\
\text { Anak }\end{array}$} & \multicolumn{3}{|c|}{ Aspek-Aspek yang dikembangkan } & \multirow{2}{*}{$\%$} & \multirow{2}{*}{ Ket } \\
\hline & & Menyimak & Berbicara & Menulis & & \\
\hline 1 & An & 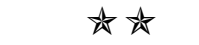 & 办 & 加加 & 58,33 & MB \\
\hline 2 & $\mathrm{Al}$ & * * & 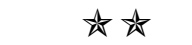 & $\star$ & 41,67 & $\mathrm{BB}$ \\
\hline 3 & $\mathrm{Ag}$ & 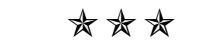 & 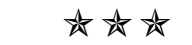 & $\star \star \star \Delta$ & 66,67 & MB \\
\hline 4 & Bs & 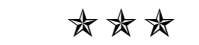 & $\star$ & 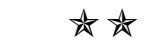 & 50 & $\mathrm{BB}$ \\
\hline 5 & $\mathrm{Ca}$ & * * & $\star \star \star \Delta$ & 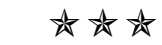 & 58,33 & MB \\
\hline 6 & Ds & $\star \star * *$ & 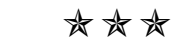 & 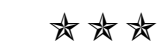 & 75 & $\mathrm{BSH}$ \\
\hline 7 & Ec & $\star * * * *$ & $\star \star \star \Delta$ & $\star \star *$ & 58,33 & $\mathrm{MB}$ \\
\hline 8 & Ic & $\star \star * *$ & 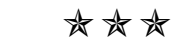 & t心 & 75 & $\mathrm{BSH}$ \\
\hline 9 & Jy & $\star * *$ & 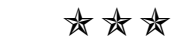 & $\star \star * t$ & 75 & $\mathrm{BSH}$ \\
\hline 10 & $\mathrm{Kt}$ & $\star \star \star$ & 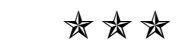 & 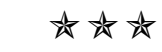 & 66,67 & MB \\
\hline 11 & $\mathrm{Me}$ & $\star *$ & 奻办办办 & $\star *$ & 66,67 & $\mathrm{MB}$ \\
\hline 12 & $\mathrm{Ma}$ & $\star \star \star ⿰ 丿 ⿱ 丄 𠃍$ & $\star \star \star x$ & $\star \star \star * t$ & 50 & $\mathrm{BB}$ \\
\hline 13 & Mi & 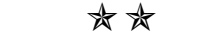 & 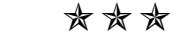 & 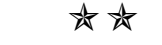 & 58,33 & MB \\
\hline 14 & $\mathrm{Nv}$ & $\star \star \star ⿰ 丿 ⿱ 丄 𠃍$ & $\star \star \star x$ & $\star$ & 41,67 & $\mathrm{BB}$ \\
\hline 15 & $\mathrm{Nw}$ & 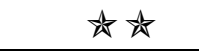 & 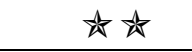 & 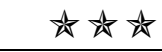 & 58,33 & $\mathrm{MB}$ \\
\hline
\end{tabular}

Keterangan :

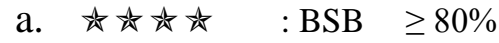
b. $\star \star \star x:$ : $\star$ BSH $70 \%-79 \%$.
c. $\star \star \quad:$ : $\star$ B $56 \%-69 \%$.
d. $\star \quad$ : BB $0 \%-55 \%$. 
Data pada tabel 3 menunjukkan bahwa belum ada anak yang berada pada kriteria penilaian BSB, 3 anak (20\%) berada pada kriteria BSH, 8 anak $(53,33 \%)$ berada pada kriteria MB, serta terdapat 4 anak $(26,67 \%)$ yang berada pada kriteria BB. Data tersebut menunjukkan bahwa perkembangan bahasa anak telah mulai berkembang, tetapi belum mencapai kriteria keberhasilan yang ditetapkan sehingga perlu dilanjutkan pada tindakan 3.

Setelah melakukan tindakan 2, maka diperoleh data sebagai berikut:

Tabel 4. Data Perkembangan Bahasa Anak Pada Siklus 1 Tindakan 3

\begin{tabular}{|c|c|c|c|c|c|c|}
\hline \multirow{2}{*}{ No } & \multirow{2}{*}{$\begin{array}{c}\text { Nama } \\
\text { Anak }\end{array}$} & \multicolumn{3}{|c|}{ Aspek-Aspek yang dikembangkan } & \multirow{2}{*}{$\%$} & \multirow{2}{*}{ Ket } \\
\hline & & Menyimak & Berbicara & Menulis & & \\
\hline 1 & An & 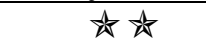 & 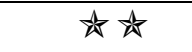 & 头办办办 & 66,67 & MB \\
\hline 2 & $\mathrm{Al}$ & $\star \star \star$ & 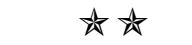 & * $\star$ & 50 & BB \\
\hline 3 & $\mathrm{Ag}$ & 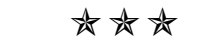 & 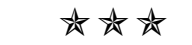 & 步击 & 66,67 & MB \\
\hline 4 & Bs & 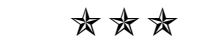 & $\star \star \star \Delta$ & 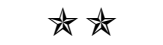 & 58,33 & MB \\
\hline 5 & $\mathrm{Ca}$ & 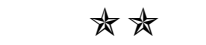 & 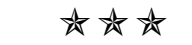 & 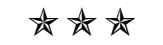 & 66,67 & MB \\
\hline 6 & Ds & 办办办 & 办办办 & 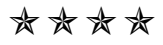 & 83,33 & BSB \\
\hline 7 & Ec & *力*力 & 办办办 & 办茲 & 75 & BSH \\
\hline 8 & Ic & 办办办办 & 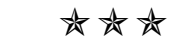 & 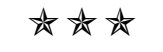 & 83,33 & BSB \\
\hline 9 & Jy & 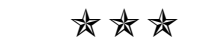 & 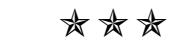 & t*t & 75 & $\mathrm{BSH}$ \\
\hline 10 & $\mathrm{Kt}$ & $\star \star \star \Delta$ & 办办文 & 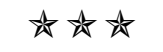 & 66,67 & MB \\
\hline 11 & $\mathrm{Me}$ & $\star \star \star x$ & 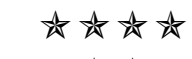 & 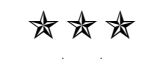 & 75 & $\mathrm{BSH}$ \\
\hline 12 & Ma & *t & 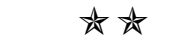 & 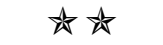 & 50 & BB \\
\hline 13 & Mi & 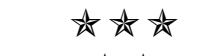 & 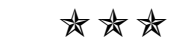 & 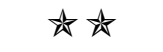 & 66,67 & MB \\
\hline 14 & $\mathrm{Nv}$ & $\star \star \star$ & $\star \star \star \Delta$ & $\star \star \star$ & 50 & $\mathrm{BB}$ \\
\hline 15 & $\mathrm{Nw}$ & 办办 & 办办办 & 办办办 & 66,67 & MB \\
\hline
\end{tabular}

Keterangan :
a. $* * t *$ : BSB $\geq 80 \%$
b. $\star *$ : $x^{\text {BSH }} 70 \%-79 \%$.
c. $\star$ : $*$ MB $56 \%-69 \%$.
d. $\star \quad$ : BB $0 \%-55 \%$.

Data pada tabel 4 menunjukkan bahwa terdapat 2 anak $(13,33 \%)$ yang berada pada kriteria penilaian BSB, 3 anak (20\%) berada pada kriteria BSH, 7 anak $(46,67 \%)$ berada pada kriteria MB, serta terdapat 3 anak (20\%) yang berada pada kriteria BB. Karena perkembangan bahasa anak belum mencapai kriteria keberhasilan yang ditetapkan maka tindakan dilanjutkan ke siklus 2 .

Siklus 2

Hasil observasi tindakan pada siklus 1 tindakan 1, menunjukkan data sebagai berikut:

Tabel 5. Data Perkembangan Bahasa Anak Pada Siklus 2 Tindakan 1

\begin{tabular}{|c|c|c|c|c|c|c|}
\hline \multirow{2}{*}{ No } & \multirow{2}{*}{$\begin{array}{l}\text { Nama } \\
\text { Anak }\end{array}$} & \multicolumn{3}{|c|}{ Aspek-Aspek yang dikembangkan } & \multirow{2}{*}{$\%$} & \multirow{2}{*}{ Ket } \\
\hline & & Menyimak & Berbicara & Menulis & & \\
\hline 1 & An & 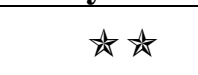 & $\star \star \star * t *$ & 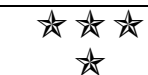 & 75 & $\mathrm{BSH}$ \\
\hline 2 & $\mathrm{Al}$ & 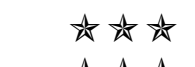 & 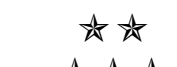 & $\star \star$ & 58,33 & MB \\
\hline 3 & $\mathrm{Ag}$ & 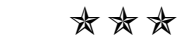 & 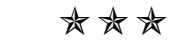 & 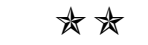 & 66,67 & MB \\
\hline
\end{tabular}




\begin{tabular}{|c|c|c|c|c|c|c|}
\hline \multirow{2}{*}{ No } & \multirow{2}{*}{$\begin{array}{l}\text { Nama } \\
\text { Anak }\end{array}$} & \multicolumn{3}{|c|}{ Aspek-Aspek yang dikembangkan } & \multirow{2}{*}{$\%$} & \multirow{2}{*}{ Ket } \\
\hline & & Menyimak & Berbicara & Menulis & & \\
\hline 4 & Bs & 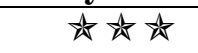 & 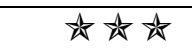 & $\star \star \star \Delta$ & 66,67 & MB \\
\hline 5 & $\mathrm{Ca}$ & $\star \star \star * * *$ & 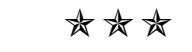 & 办办办 & 75 & $\mathrm{BSH}$ \\
\hline 6 & Ds & $\star \star \star \Delta * t$ & 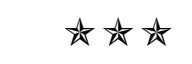 & 市 & 83,33 & BSB \\
\hline 7 & $\mathrm{Ec}$ & 办办办 & 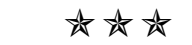 & $\star \star \star \Delta$ & 75 & $\mathrm{BSH}$ \\
\hline 8 & Ic & 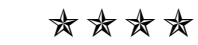 & 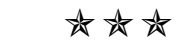 & 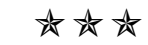 & 83,33 & BSB \\
\hline 9 & Jy & $\star \star \star \Delta *$ & 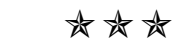 & 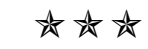 & 75 & $\mathrm{BSH}$ \\
\hline 10 & $\mathrm{Kt}$ & $\star \star \star x$ & $\star \star * \star * ⿻ 一 丿 火$ & *t* & 75 & BSH \\
\hline 11 & $\mathrm{Me}$ & 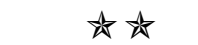 & $\star \star \star \star * \star * t *$ & 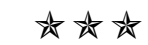 & 75 & $\mathrm{BSH}$ \\
\hline 12 & Ма & 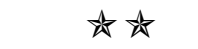 & 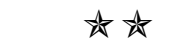 & 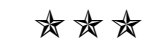 & 58,33 & MB \\
\hline 13 & Mi & 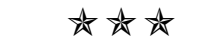 & 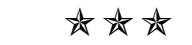 & 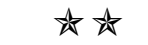 & 66,67 & MB \\
\hline 14 & Nv & 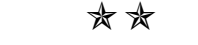 & 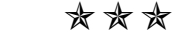 & 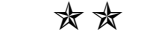 & 58,33 & MB \\
\hline 15 & $\mathrm{Nw}$ & 办办办 & 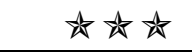 & 办办 & 75 & $\mathrm{BSH}$ \\
\hline \multicolumn{5}{|c|}{ Jumlah Ra } & \multicolumn{2}{|c|}{$71,11 \%$} \\
\hline
\end{tabular}

Keterangan :
a. $* t *$ : $*$ BSB $\geq 80 \%$
b. $\star * *$ : BSH $70 \%-79 \%$.
c. $\star * \quad$ : $* 56 \%-69 \%$.
d. $\star \quad$ : BB $0 \%-55 \%$.

Data pada tabel 5 menunjukkan bahwa telah terdapat 2 anak (13,33\%) yang berada pada kriteria penilaian BSB, 7 anak $(46,67 \%)$ berada pada kriteria BSH, 6 anak $(40 \%)$ berada pada kriteria MB, dan tidak ada anak yang berada pada kriteria BB. Data tersebut menunjukkan bahwa perkembangan bahasa anak terus berkembang, tetapi belum mencapai kriteria keberhasilan yang ditetapkan sehingga perlu dilanjutkan pada tindakan 2.

Setelah melakukan observasi terhadap tindakan 2, maka diperoleh data sebagai berikut:

Tabel 6. Data Perkembangan Bahasa Anak Pada Siklus 2 Tindakan 2

\begin{tabular}{|c|c|c|c|c|c|c|}
\hline \multirow{2}{*}{ No } & \multirow{2}{*}{$\begin{array}{l}\text { Nama } \\
\text { Anak }\end{array}$} & \multicolumn{3}{|c|}{ Aspek-Aspek yang dikembangkan } & \multirow{2}{*}{$\%$} & \multirow{2}{*}{ Ket } \\
\hline & & Menyimak & Berbicara & Menulis & & \\
\hline 1 & An & *t & 加妨办 & $\begin{array}{c}\star \star \star \star * t \\
\star\end{array}$ & 75 & $\mathrm{BSH}$ \\
\hline 2 & $\mathrm{Al}$ & 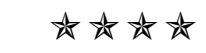 & $\star \star *$ & $\star \star \star 力 ~$ & 66,67 & $\mathrm{MB}$ \\
\hline 3 & $\mathrm{Ag}$ & 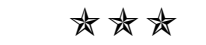 & 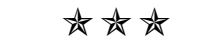 & 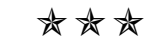 & 75 & $\mathrm{BSH}$ \\
\hline 4 & Bs & 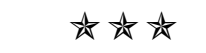 & 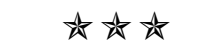 & 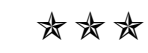 & 75 & $\mathrm{BSH}$ \\
\hline 5 & $\mathrm{Ca}$ & 办办办办 & $\star \star * *$ & 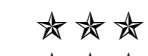 & 83,33 & BSB \\
\hline 6 & Ds & 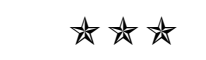 & 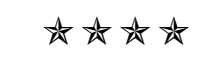 & 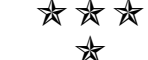 & 91,67 & BSB \\
\hline 7 & $\mathrm{Ec}$ & $\star \star \star * t * t$ & $\star \star \star * t$ & $\star \star \star$ & 75 & $\mathrm{BSH}$ \\
\hline 8 & Ic & 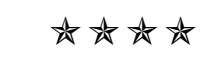 & $\star \star \star \star * ⿻ 一 丿 火$ & 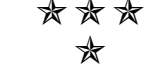 & 91,67 & BSB \\
\hline 9 & Jy & 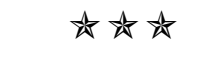 & 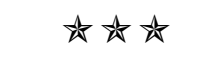 & 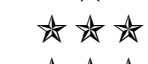 & 75 & $\mathrm{BSH}$ \\
\hline 10 & $\mathrm{Kt}$ & $\star \star *$ & *t* & *t* & 75 & $\mathrm{BSH}$ \\
\hline 11 & $\mathrm{Me}$ & $\star \star \star x$ & 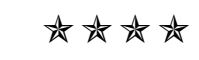 & $\star \star \star \star * t$ & 75 & $\mathrm{BSH}$ \\
\hline 12 & $\mathrm{Ma}$ & $\star \star \star x$ & $\star * *$ & 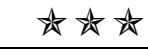 & 66,67 & $\mathrm{MB}$ \\
\hline
\end{tabular}




\begin{tabular}{|c|c|c|c|c|c|c|}
\hline \multirow{2}{*}{ No } & \multirow{2}{*}{$\begin{array}{l}\text { Nama } \\
\text { Anak }\end{array}$} & \multicolumn{3}{|c|}{ Aspek-Aspek yang dikembangkan } & \multirow{2}{*}{$\%$} & \multirow{2}{*}{ Ket } \\
\hline & & Menyimak & Berbicara & Menulis & & \\
\hline 13 & Mi & 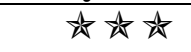 & *t* $*$ & 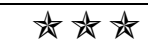 & 75 & BSH \\
\hline 14 & Nv & 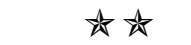 & 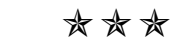 & 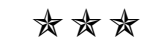 & 66,67 & MB \\
\hline 15 & $\mathrm{Nw}$ & 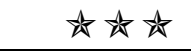 & 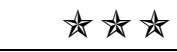 & 办办办 & 75 & BSH \\
\hline \multicolumn{5}{|c|}{ Jumlah Rata-Rata $=1.141,68 / 15$} & \multicolumn{2}{|c|}{$76,11 \%$} \\
\hline
\end{tabular}

Keterangan :
a. $\star \star * \star * \quad:$ BSB $\geq 80 \%$
b. $* *$ : $*$ BSH $70 \%-79 \%$.
c. $\star \star \quad: \mathrm{MB} \quad 56 \%-69 \%$.
d. $\star$ : BB $0 \%-55 \%$.

Data pada tabel 6 menunjukkan bahwa telah terdapat 3 anak (20\%) yang berada pada kriteria penilaian BSB, 9 anak (60\%) berada pada kriteria BSH, 3 anak (20\%) berada pada kriteria MB, dan tidak ada anak yang berada pada kriteria BB. Karena perkembangan bahasa anak belum mencapai kriteria keberhasilan yang ditetapkan maka tindakan dilanjutkan pada tindakan 3.

Setelah melakukan observasi terhadap tindakan 3, maka diperoleh data sebagai berikut:

Tabel 7. Data Perkembangan Bahasa Anak Pada Siklus 2 Tindakan 3

\begin{tabular}{|c|c|c|c|c|c|c|}
\hline \multirow{2}{*}{ No } & \multirow{2}{*}{$\begin{array}{l}\text { Nama } \\
\text { Anak }\end{array}$} & \multicolumn{3}{|c|}{ Aspek-Aspek yang dikembangkan } & \multirow{2}{*}{$\%$} & \multirow{2}{*}{ Ket } \\
\hline & & Menyimak & Berbicara & Menulis & & \\
\hline 1 & An & 加加 & 加泫 & 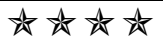 & 83,33 & $\mathrm{BSB}$ \\
\hline 2 & $\mathrm{Al}$ & *炏炏 & $\star \star \star x$ & $\star \star \star * t$ & 75 & $\mathrm{BSH}$ \\
\hline 3 & $\mathrm{Ag}$ & 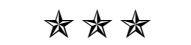 & 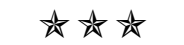 & 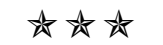 & 75 & $\mathrm{BSH}$ \\
\hline 4 & Bs & 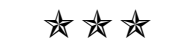 & 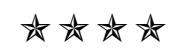 & $\star \star \star \star \star ⿰ 丿 ⿱ 丄 𠃍 力$ & 83,33 & BSB \\
\hline 5 & $\mathrm{Ca}$ & 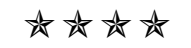 & 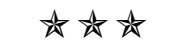 & *t心 & 83,33 & BSB \\
\hline 6 & Ds & 加加 & 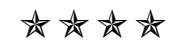 & $\star \star * * * t *$ & 91,67 & BSB \\
\hline 7 & Ec & 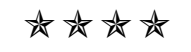 & **t & 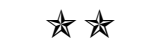 & 75 & $\mathrm{BSH}$ \\
\hline 8 & Ic & 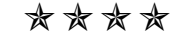 & t心 & 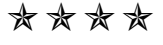 & 91,67 & BSB \\
\hline 9 & Jy & 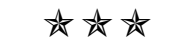 & 办办办办 & 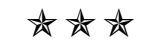 & 91,67 & BSB \\
\hline 10 & $\mathrm{Kt}$ & 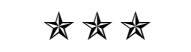 & 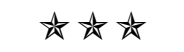 & 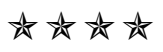 & 83,33 & BSB \\
\hline 11 & $\mathrm{Me}$ & 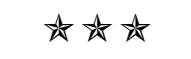 & 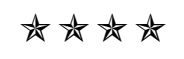 & 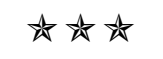 & 83,33 & BSB \\
\hline 12 & $\mathrm{Ma}$ & 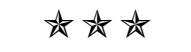 & 办办办 & 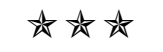 & 75 & $\mathrm{BSH}$ \\
\hline 13 & Mi & 办办办 & 办办 & 办办办办 & 83,33 & BSB \\
\hline 14 & $\mathrm{Nv}$ & 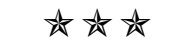 & 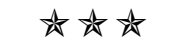 & 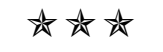 & 75 & $\mathrm{BSH}$ \\
\hline 15 & $\mathrm{Nw}$ & 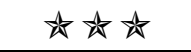 & 办办办 & 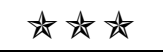 & 75 & $\mathrm{BSH}$ \\
\hline
\end{tabular}

Keterangan :
a. $\star * \star * *:$ BSB $\geq 80 \%$

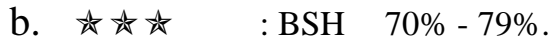
c. $\star$ : $\star$ MB $56 \%-69 \%$.
d. * $\quad$ : BB $0 \%-55 \%$.

Data pada tabel 7 menunjukkan bahwa perkembangan bahasa anak telah berkembang dengan baik. Hal itu ditunjukkan dari hasil observasi bahwa telah terdapat 9 anak $(60 \%)$ yang berada pada kriteria penilaian BSB, 6 anak $(40 \%)$ berada pada kriteria $\mathrm{BSH}$, serta tidak ada lagi anak yang berada pada kriteria penilaian MB dan BB. 
Secara klasikal, perkembangan bahasa anak telah mencapai $81,66 \%$ yang berarti telah mencapai kriteria keberhasilan yang ditetapkan yaitu sebesar $80 \%$, sehingga tindakan penelitian dianggap berhasil dan dihentikan.

Untuk melihat rekapitulasi hasil penelitian dapat dilihat pada tabel 8:

Tabel 8. Rekapitulasi Perkembangan Bahasa Anak

\begin{tabular}{|c|c|c|c|c|c|c|c|c|}
\hline No & Nama & DA/\% & S1T1/\% & S1T2/\% & S1T3/\% & S2T1/\% & S2T2/\% & S2T3/\% \\
\hline 1 & An & 41,67 & 41,67 & 58,33 & 66,67 & 75 & 75 & 83,33 \\
\hline 2 & $\mathrm{Al}$ & 41,67 & 41,67 & 41,67 & 50 & 58,33 & 66,67 & 75 \\
\hline 3 & $\mathrm{Ag}$ & 50 & 50 & 66,67 & 66,67 & 66,67 & 75 & 75 \\
\hline 4 & $\mathrm{Bs}$ & 50 & 50 & 50 & 58,33 & 66,67 & 75 & 83,33 \\
\hline 5 & $\mathrm{Ca}$ & 33,33 & 33,33 & 58,33 & 66,67 & 75 & 83,33 & 83,33 \\
\hline 6 & Ds & 75 & 75 & 75 & 83,33 & 83,33 & 91,67 & 91,67 \\
\hline 7 & Ec & 50 & 50 & 58,33 & 75 & 75 & 75 & 75 \\
\hline 8 & Ic & 58,33 & 58,33 & 75 & 83,33 & 83,33 & 91,67 & 91,67 \\
\hline 9 & Jy & 66,67 & 66,67 & 75 & 75 & 75 & 75 & 91,67 \\
\hline 10 & $\mathrm{Kt}$ & 58,33 & 58,33 & 66,67 & 66,67 & 75 & 75 & 83,33 \\
\hline 11 & $\mathrm{Me}$ & 50 & 50 & 58,33 & 75 & 75 & 75 & 83,33 \\
\hline 12 & $\mathrm{Ma}$ & 33,33 & 33,33 & 50 & 50 & 58,33 & 66,67 & 75 \\
\hline 13 & $\mathrm{Mi}$ & 41,67 & 41,67 & 58,33 & 66,67 & 66,67 & 75 & 83,33 \\
\hline 14 & $\mathrm{Nv}$ & 41,67 & 41,67 & 41,67 & 50 & 58,33 & 66,67 & 75 \\
\hline 15 & $\mathrm{Nw}$ & 33,33 & 33,33 & 58,33 & 66,67 & 75 & 75 & 75 \\
\hline \multicolumn{2}{|c|}{$\begin{array}{c}\text { Jumlah Rata- } \\
\text { Rata }\end{array}$} & 48,33 & 53,88 & 60 & 66,67 & 71,11 & 76,11 & 81,66 \\
\hline
\end{tabular}

Keterangan:

$\begin{array}{lll}\text { a. } & \text { DA } & \text { : Data Awal/Pra Siklus } \\ \text { b. } & \text { S1T1 } & \text { : Siklus 1 Tindakan 1 } \\ \text { c. } & \text { S1T2 } & \text { : Siklus 1 Tindakan 2 } \\ \text { d. } & \text { S1T3 } & \text { : Siklus 1 Tindakan 1 } \\ \text { e. } & \text { S2T1 } & \text { : Siklus 2 Tindakan 1 } \\ \text { f. } & \text { S2T2 } & \text { : Siklus 2 Tindakan 2 } \\ \text { g. } & \text { S2T3 } & \text { : Siklus 2 Tindakan 1 }\end{array}$

PEMBAHASAN

Hasil penelitian menunjukkan adanya peningkatan perkembangan bahasa anak usia 5-6 tahun melalui penggunaan media boneka jari di TK Pelangi Genyem Kabupaten Jayapura. Pola peningkatan perkembangan bahasa tersebut dapat dilihat dari data sebelum tindakan, siklus 1 dan siklus 2. Data sebelum tindakan menunjukkan ratarata perkembangan bahasa anak hanya sebesar $48,33 \%$. Pada siklus 1 tindakan 1 mengalami peningkatan 53,88\%, pada siklus 1 tidakan 2 meningkat menjadi $60 \%$, pada siklus 1 tindakan 3 meningkat lagi menjadi 66,67\%. Selanjutnya pada siklus 2 tindakan 1 perkembangan bahasa anak meningkat menjadi 71,11\%, pada siklus 2 tindakan 2 menjadi $76,11 \%$, dan pada siklus 2 tindakan 3 terjadi peningkatan sebesar 81,66\% sehingga telah mencapai kriteria ketuntasan minimum yang ditetapkan yaitu sebesar $80 \%$. Oleh karena itu dapat dikatakan perkembangan bahasa melalui penggunaan media boneka jari pada anak usia 5-6 tahun di TK Pelangi Genyem Kabupaten Jayapura meningkat dengan baik. Penerapan penggunaan media boneka jari dalam pembelajaran berbahasa dapat mencapai hasil yang baik dan optimal, dengan pemberian berbagai 
macam bentuk media boneka jari yang menarik sehingga anak lebih antusias untuk mengikuti pembelajaran, anak lebih aktif dan kreatif dalam pembelajaran serta anak dapat berekspresi sehingga kemampuan bahasanya dapat meningkat dengan baik. Hasil penelitian ini didukung oleh penelitian (Utariani et al., 2014) bahwa metode bercerita berbantuan boneka jari dapat meningkatkan kemampuan berbahasa pada anak; (Karuniawati, 2018) bahwa penggunaan metode bercerita dengan boneka jari dapat menstimulasi kemampuan berbahasa anak dan perkembangan anak. (Marlinda et al., 2014) bahwa media boneka jari dapat meningkatkan kemampuan berbahasa lisan anak. (Ulya et al., 2019) bahwa metode bercerita dengan media boneka jari dapat mengembangkan kemampuan bahasa anak. Serta hasil penelitian (Aprillina et al., 2020) bahwa metode bercerita dengan boneka tangan dapat mengembangkan kemampuan bahasa anak. Hal ini menunjukkan bahwa hasil penelitian ini menghasilkan suatu kebaruan untuk memperluas subjek (dengan latar belakang sosial ekonomi yang berbeda) serta wilayah penelitian pada topik yang diteliti.

\section{SIMPULAN}

Merujuk pada hasil penelitian di atas, diperoleh kesimpulan bahwa penggunaan media boneka jari dapat meningkatkan perkembangan bahasa anak usia 5-6 tahun di TK Pelangi Genyem Kabupaten Jayapura. Hal itu dapat dilihat dari kondisi awal kemampuan berbahasa anak yang hanya mencapai 48,33\%. Pada siklus 1 tindakan 1 menjadi 53,88\%, dan meningkat lagi pada siklus 1 tindakan 2 menjadi 60\%, dan pada siklus 1 tindakan 3 meningkat menjadi 66,67\%. Selanjutnya pada siklus 1I tindakan 1 menjadi $71,11 \%$, Pada siklus 1I tindakan 2 nilai meningkat menjadi $76,11 \%$, dan pada sikus II tindakan 3 meningkat lagi menjadi 81,66\%.

\section{UCAPAN TERIMA KASIH}

Ucapan terima kasih kami sampaikan kepada pimpinan Fakultas Keguruan dan Ilmu Pendidikan Universitas Cenderawasih yang telah memberikan dukungan dalam pelaksanaan penelitian ini..

\section{REFERENSI}

Amelia, L., \& Marsella, A. (2018). Meningkatkan Kemampuan Interpersonal Anak Melalui Metode Bermain Peran Dengan Menggunakan Boneka Jari Pada Anak TK B2 di PAUD Save The Kids Banda Aceh. Jurnal Buah Hati, 5(2), 81-102. https://doi.org/10.46244/BUAHHATI.V5I2.570

Anjeli, Y. N., \& Latifah, N. (2021). Pengembangan Media Boneka Jari Terhadap Keterampilan Berbicara Siswa Kelas IV SDN Saga VI Kabupaten Tangerang. WACANA AKADEMIKA: Majalah Ilmiah Kependidikan, 5(1), 1-7. https://doi.org/10.30738/WA.V5I1.8444

Aprillina, N. Z., Ahmad, A., \& Rahmi. (2020). Mengembangkan Kemampuan Bahasa Anak Melalui Metode Bercerita Dengan Boneka Tangan Di Tk Aba Manggeng Kabupaten Aceh Barat Daya. Jurnal Ilmiah Mahasiswa Pendidikan Anak Usia Dini, 5(2), 22-33. http://www.jim.unsyiah.ac.id/paud/article/view/15310

Ayuni, G. A. M., Wirya, I. N., \& Asril, N. M. (2014). Penerapan Metode Bcct Berbantuan Media Boneka Jari Pada Kemampuan Berbicara Anak Kelompok A Tk Saiwa Dharma. Jurnal Pendidikan Anak Usia Dini Undiksha, 2(1). https://doi.org/10.23887/PAUD.V2I1.3153

Dewi, K. Y. O., Suwatra, I. W., \& Magta, M. (2016). Penerapan Metode Bercerita 
Berbantuan Media Boneka Jari Untuk Meningkatkan Kemampuan Menyimak Anak Di Tk Waringin Sari. Jurnal Pendidikan Anak Usia Dini Undiksha, 4(3). https://doi.org/10.23887/PAUD.V4I3.8896

Elisa, R. S., Sutisnawati, A., \& Nurasiah, I. (2020). Pengaruh Media Boneka Jari Kertas Terhadap Keterampilan Berbicara Di Kelas Rendah. Jurnal Perseda: Jurnal Pendidikan Guru Sekolah Dasar, 3(1), 1-5. https://doi.org/10.37150/PERSEDA.V3I1.451

Hidayati, D. R., \& Affrida, E. N. (2020). Mengembangkan Kemampuan Berkomunikasi Anak Melalui Metode Bercerita Dengan Media Hand Puppet. Incrementapedia: Jurnal Pendidikan Anak Usia Dini, 2(01), 37-42. https://doi.org/10.36456/INCREMENTAPEDIA.VOL2.NO01.A2516

Karuniawati, N. N. A. (2018). Penggunaan Metode Bercerita dengan Boneka Jari Untuk Meningkatkan Kemampuan Berbahasa Anak Usia 5-6 Tahun. SENDIKA: Seminar Pendidikan, 2(1), 109-112. http://seminar.uad.ac.id/index.php/sendika/article/view/3588

Khairunnisa, R., \& Oye, S. (2020). Implementasi Penggunaan Media Boneka Jari Untuk Mengembangan Kemampuan Interpersonal Siswa SDN 027 Samarinda Ulu. EduTeach: Jurnal Edukasi Dan Teknologi Pembelajaran, 1(2), 137-143. https://doi.org/10.37859/EDUTEACH.V1I2.1945

Marlinda, N. L. D., Wirya, I. N., \& Tirtayani, L. A. (2014). Penerapan Metode Bercerita Berbantuan Media Boneka Jari Untuk Meningkatkan Kemampuan Berbahasa Lisan. Jurnal Pendidikan Anak Usia Dini Undiksha, 2(1). https://doi.org/10.23887/PAUD.V2I1.3155

Oktiawati, A., Widodo, Y. P., \& Istianah, N. (2020). Storytelling Media Boneka Jari Kain Flanel Meningkatkan Kecerdasan Emosional Anak Usia Prasekolah. Bhamada: Jurnal Ilmu Dan Teknologi Kesehatan (E-Journal), 11(2), 9-9. https://doi.org/10.36308/JIK.V1112.235

Ramadani, R. (2016). Meningkatkan Keterampilan Berbicara Melalui Penggunaan Media Panggung Boneka Pada Kelompok A1tk Madukismo. Jurnal Pendidikan Anak, 5(2), 808-816. https://doi.org/10.21831/JPA.V5I2.12378

Sukerti, D. T. (2013). Peningkatan Hasil Belajar Siswa Pada Pembelajaran Percakapan Sederhana Dengan Boneka Jari Di Kelas I [Universitas Tanjungpura Pontianak]. In Jurnal Pendidikan dan Pembelajaran Khatulistiwa (Vol. 2, Issue 6). https://jurnal.untan.ac.id/index.php/jpdpb/article/view/2322

Suyanto. (2005). Konsep Dasar Anak Usia Dini. Departemen Pendidikan Nasional.

Triyuwanti, S., \& Widha, L. (2018). Penerapan Boneka Jari Sebagai Media Bimbingan Untuk Meningkatkan Kecerdasan Spiritual Anak Di Learning Quran For All (Lqa) Sahabat-Qu Yogyakarta. Al-Isyraq: Jurnal Bimbingan, Penyuluhan, Dan Konseling Islam, 1(2), 1. https://doi.org/10.15575/alisyraq.v1i2.13

Ulya, R., Ahmad, A., \& Bahrun. (2019). Mengembangkan Kemampuan Bahasa Anak Melalui Metode Bercerita Dengan Media Boneka Jari Di PAUD Al Kamal Kabupaten Aceh Besar. Jurnal Ilmiah Mahasiswa Pendidikan Anak Usia Dini, 4(4), 25-33. http://www.jim.unsyiah.ac.id/paud/article/view/15273

Utariani, N. K., Sudarma, I. K., \& Magta, M. (2014). Penerapan Metode Bercerita Berbantuan Media Boneka Jari Untuk Meningkatkan Kemampuan Berbahasa Anak. Jurnal Pendidikan Anak Usia Dini Undiksha, 2(1). https://doi.org/10.23887/paud.v2i1.3264

Yosastra, O., Azwandi, Y., \& Sopandi, A. A. (2013). Efektifitas Permainan Boneka Jari 
Untuk Meningkatkan Kemampuan Pengurangan Bilangan Bulat Bagi Anak Tunagrahita X. Jurnal Penelitian Pendidikan Khusus, 2(3), 671-681. https://doi.org/10.24036/JUPE21150.64 